\title{
Combined Single Step Definitive Treatment in Acute Pilonidal Sinus Abscess Running Head: Single Step Treatment of Pilonidal Abscess
}

\author{
Dogan Yildirim ${ }^{1}$, Oguzhan Sunamak ${ }^{2}$, Ahmet Pergel ${ }^{3}$, Mourad Mounla ${ }^{1}$ \\ ${ }^{1}$ General Surgeon, Private Yildiztabya Bilge Hospital, General Surgery Clinics, Istanbul, Turkey \\ ${ }^{2}$ General Surgeon, Izmir Kemalpasa Hospital, General Surgery Clinics, Izmir, Turkey \\ ${ }^{3}$ General Surgeon, Private Avrasya hospital, General Surgery Clinics, Istanbul, Turkey \\ E-mail: toredr@yahoo.com \\ Received February 20, 2010; accepted July 7, 2010
}

\begin{abstract}
Backgrounds: The treatment of choice has been drainage and definitive surgical treatment after an interval for acute pilonidal sinus abscess till now. Because o $\mathrm{f}$ the high incidence of ch ronic pilonidal sinus disease following dra inage and aiming the cure in one step, sy nchronous treat ment choices to drainage have bee $\mathrm{n}$ attempted recently. We analyzed retrospectively 20 patients with pilonidal sinus abscess on whom we carried out drainage + marsupialization as singl e-step treatment. Methods: Drainage + sy nchronous marsupialization results of 20 patients ( 17 male, 3 female) between 20 to 37 years of age (mean 28) were analy zed retrospectively on the para meters of operation time, recov ery period, time to work-r eturn and recurrence ratios. Results Operation times were between 15 to 25 minutes. Mean recovery perio d was 45 days (30-50 days), the mean period from operation to work-return was 24 (22-30) days. There were full recovery in 18 patients $(90 \%)$ and recurrence in 2 patients $(10 \%)$. Silver nitr ate ablation treat ment ac hieved cure in recurrence s. Conclusion: Drainage + Marsupialization is an applicable and successful combined choice in the treatment of Pilonidal sinus abscess.
\end{abstract}

Keywords: Pilonidal Sinus Abscess, Drainage, Marsupialization, Definitive Treatment, Combined Treatment

\section{Introduction}

Pilonidal si nus disease (PSD) is an ac quired disease in especially yo ung $\mathrm{m}$ en $\mathrm{w}$ ith continuous oozin $\mathrm{g}$ at $\mathrm{i}$ ntergluteal sulcus [1]. The risk factors increasing PSD inci dence are white race, young age, familial tendency, excessive sweating, long sitting periods, sedative life style, bad body sanitation, fatn ess, male gender and trau ma to the coccyx region [2].

In sp ite of proposed different treatm ent modalities, there is no standardized treatment due to high recurrence ratio.

Pilonidal sinus abscess (PSA) (Figure 1) is seen as the first find ing in $h$ alf of the patients [3]. PSA may cau se widening of lesion, increasing of sinus number and se psis [ 1,2$]$. It $\mathrm{m}$ ay be fatal i $\mathrm{f}$ remains unt reated. Various complications lik e Sep tic arth ritis, osteomyelitis, DIC, and tox ic shock syndrome $w$ ere $r$ eported $[2,4,5,6]$. The treatment of PSA has been simple drainage and definitive surgery after healing of abscess [7]. Because the rec ur- rence is high following simp le drain age, definitive surgery is necessary for $t$ otal cu re [8]. Today, alternative approaches that combine drainage and definitive surgery in one step get popularity. We reported 20 patients with PSA t $o$ who $m$ we $p$ erformed d efinitive su rgery at th e same time with drainage.

\section{Methods}

20 patients (17 (85\%) male and $3(15 \%)$ female) between 20 to 37 years of ag e (median 28) who came to our outpatient clin ics with acu te pilonidal si nus abscess (PSA) and operated between 2007 and 2009 were analyzed retrospectively.

All patients were treated with skin excision, curettage and in traflexion operation under spinal an esthesia. Metronidazole $0.5 \mathrm{mg}$ IV and gentamicin $80 \mathrm{mg}$ IV were given to the pts 30 minutes before operation for infection treatment. Gluteal skin stretched to both sides with plaster traction a nd the area was shave d. Absc ess was dra- 
ined at $\mathrm{m}$ idline where it gave fl uctuation and th e sk in around the area was rem oved by a vertical rh omboid excision paralleling the in tergluteal su lcus ( Figure 2). The abscess p ouch was washed out wi th phy siologic saline an d $10 \%$ p ovidine i odine s olutions. The wall of cavity was cu retted and c hronic gra nulation t issue wa $\mathrm{s}$ excised (Figure 3). Healthy skin was fixed to the sacral fascia with $2 / 0$ po lypropylene sing le stitch at sup erior, inferior and both lateral sid es (marsupialization) (Figure 4). The mean operation time was between 15 to 25 minutes. Pts were given po ampicillin $375 \mathrm{mg}$ three times a day for 5 day s and discharged at post operative $2^{\text {nd }}$ day. Serum phy siologic dressing of the w ound was made on every 2 days for first 10 post operative days and on every $3 \mathrm{~d}$ ay-interval after th en until to tal wo und healing occurred. Pts were a dvised to take s hower before e very dressing. Stitches were removed on $15^{\text {th }}$ day and periodical controls were made at $1^{\text {st }} 2^{\text {nd }} 3^{\text {rd }} 6^{\text {th }}$ and $12^{\text {th }}$ months (Figure 5).

\section{Findings}

Abscess pouch was $r$ unning toward to the right gl uteal region in $13(65 \%)$, to the left in $5(25 \%)$ and to the superior in $2(2 \%)$ of pts. Mean reco very period was 45

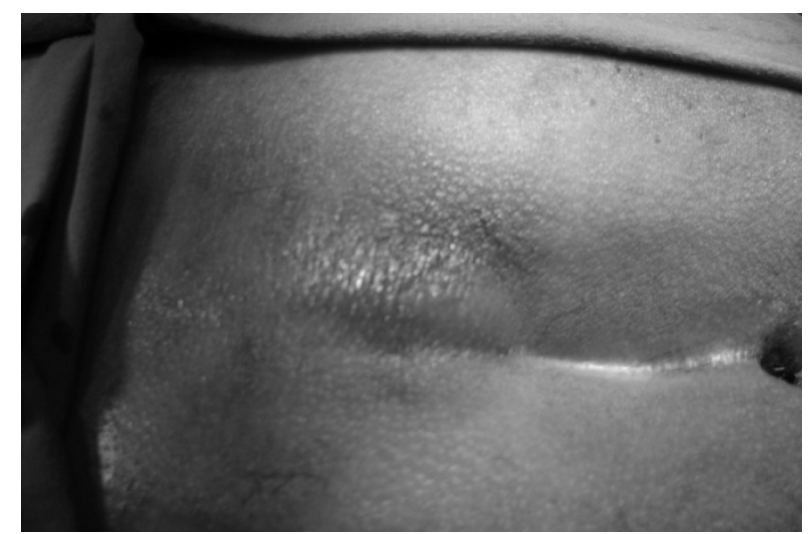

Figure 1: Pilonidal sinus abscess.

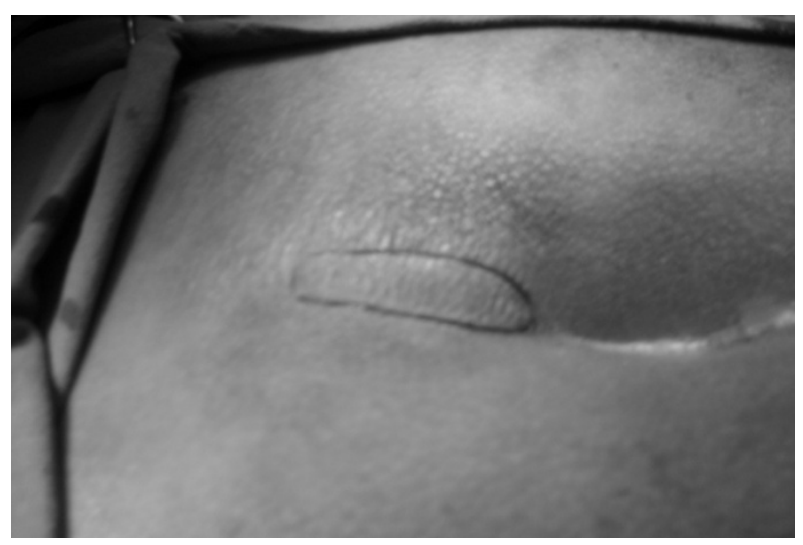

Figure 2. Line of excision.

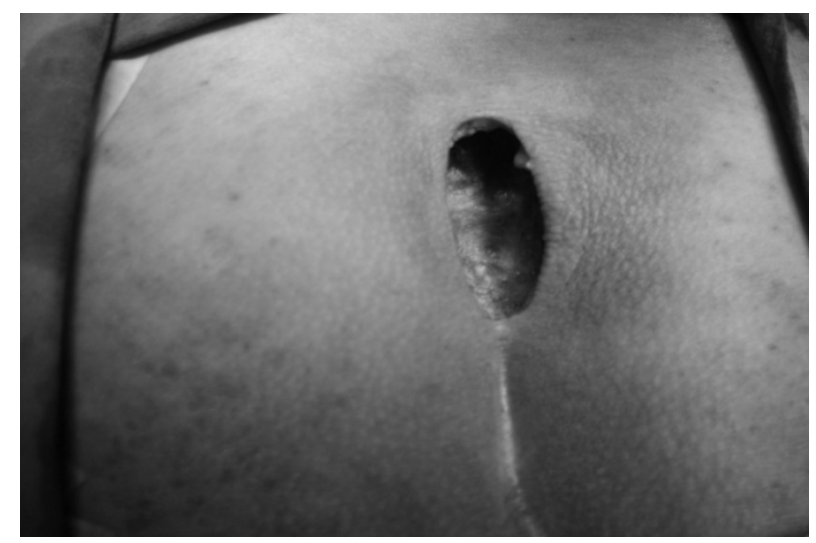

Figure 3. Cavity after curettage and washing.

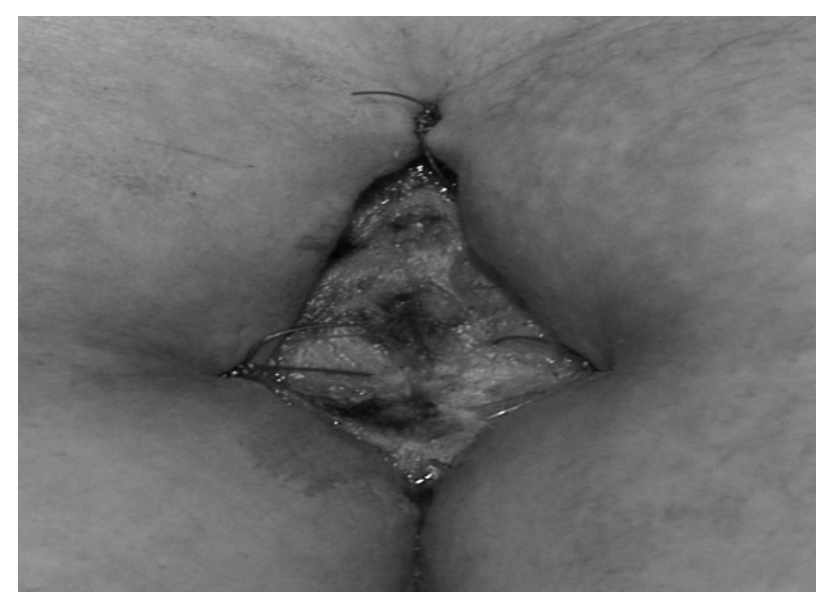

Figure 4. Marsupialization.

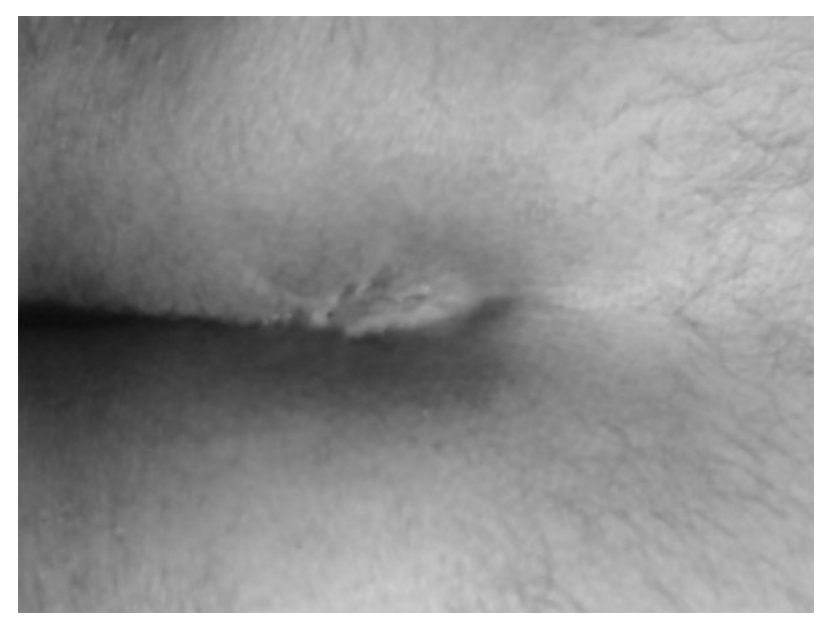

Figure 5. Healing scar at the 6th month.

days (between 30 to 50 days); the mean work-return period w as 24 days ( $22-30) .18(90 \%)$ of pts shown to tal recovery though 2 pts $(10 \%)$ developed chronic pilonidal sinus disease on midline. These 2 pts were treated wit h silver $n$ itrate $20 \%$ solution ablation and reco vered well. There was no recurrence in follow up period. 


\section{Results and Discussion}

Mainstay of $t$ he treatm ent is d rainage for PS A. Si mple drainage an d definitive su rgery after an interv al period has been accepted treatment. But, $m$ any of the patients, treated with simple drainage, develop chronic PDS until definitive su rgery an $d$ an y delay in definitive sur gery may resul $t$ in expansion of diseased are a and development of ne w tracts, $t$ herefore, wi dening $t$ he operative field. To decrease chronic PSD development risk, drainage and co mbined definitive su rgery con cept was pro posed. D rainage $+\mathrm{m}$ arsupialization was performed by Licheri on 43 patients with a cute abscess and succeeded in $81.3 \%$ of them. In t his study, $4.7 \%$ of the pts developed chronic fi stulas and 14.6 de veloped recurrence. $95 \%$ of the pts got totally recovered within 6 to 10 weeks [9]. Our pts number was half of that series, but still, operation ti mes were similar. Ou $\mathrm{r}$ recu rrence ratio was twice.

Midline skin excision provided easier drainage, cavity curettage and excision of chronic granulation tissue.

Disadvantages of the method were long recovery and work-return periods.

Another method reported as successful was drainage + primary closure with $82 \%$ total recovery and $18 \%$ recurrence [10]. Drainage +1 aying open was a nother recommended method [11].

Midline lo cation of th e sinu s openings mostly in chronic and recurred PSD s uggest that focus of the disease is $\mathrm{m}$ idline. Thus, $\mathrm{t}$ wo studies which $\mathrm{closed} \mathrm{w}$ ound off-midline sh own $t$ hat $t$ his $t$ ype of cl osure i mproved wound healing $[12,13]$.

\section{Conclusions}

PSA n eeds d efinitive treatm ent after drain age so that it should not become chronic disease. Draina ge and combined definitive surgery (sk in ex cision curettage and intraflexion operation) as a single step is a good alternative method in its treatment. This treatment provides the patient to be cured in one step s urgery and excludes the complications of delay in d efinitive surgery, like risk of getting $\mathrm{c}$ hronic di sease and forming $\mathrm{m}$ ore si nus $\mathrm{t}$ racts. The results are $\mathrm{p}$ romising with low recu rrence rate and small and $g$ ood scar formation a nd f uture st udies o $n$ more patients will show its efficiency.

\section{References}

[1] R. Eryilmaz, M. Sahin, O. Alimoglu and B. Kay a, "The Comparison of Incision and Drainage with Skin Excision and Cure ttage in the Tr eatment of Acu te Pilon idal Abscess," Ulusal Travma ve Acil Cerrahi Derneği, Vol. 9, No. 2, April 2003, pp. 120-123.

[2] J. Ivan a, L. Gra ndic, A. Tonk ic, et al., "Sepsis-Induced Disseminated In travascular Coa gulation: A Rar e Com plication of Sacrococcy geal Pilonidal Sinus Disease,' Mount Sinai Journal of Medicine, Vol. 73, No. 8, December 2006, pp. 1170-1172.

[3] T. G. Allen-Mersh, "Piloni dal Sinus: Finding the Right Track for Treatment," British Journal of Surgery, Vol. 77, No. 22, 1990, pp. 123-132.

[4] A. Verdu, E. Garcia-Granero, M. J. Gar cia-Fuster, et al., "Osteomyelitis and Epidural A bscess Com plicating Recurrent Pilonidal Cyst: Report of a Case," Diseases of the Colon \& Rectum, Vol. 43, No. 7, 2000, pp. 1015-1017.

[5] A. Borer, G. Weber, K. Riesenberg, et al., "Septic Arthritis Due to Bacteroides Frag ilis after Pilonidal Sinus Resection in a Patient with Rheumatoid Arthritis," Clinical Rheumatology, Vol. 16, No. 6, 1997, pp. 632-634.

[6] N. Velitchkov, M. Dj edjev, G. Kirov, et al., "T oxic Shock Syndrome and Necrotizing Fasciitis Complicating Neglected S acrococcygeal P ilonidal S inus Dis ease: Report of a Case," Diseases of the Colon \& Rectum, Vol. 40, No. 11, 1997, pp. 1386-1390.

[7] A. Heg ele, F. J . Stromb ach and F. Schönbach, "Reconstructive S urgical Therapy of I nfected P ilonidal S inus," Chirurgie, Vol. 74, No. 8, August 2003, pp.749-52.

[8] P. Goodall, "Th e A etiology and Tr eatment of Pilonidal Sinus: A Rev iew of 163 Patients," British Journal of Surgery, Vol. 49, No. 214, 1961, pp. 212-218.

[9] S. Licheri, G. Pisano, E. Erdas, et al., "Radical Treatment of Acute Pilo nidal Absce ss b y Marsupi alization," Giornale di Churirgia, Vol. 25 , No. 11-12, NovemberDecember 2004, pp. 414-416.

[10] A. Ommer, C. Pitt, K. Albrecht, et al., "Pilonidal SinusPrimary C losure als o in C ase of Abs cess?" Zentralblatt fur Chirurgie, Vol. 129, No. 3, June 2004, pp.216-219.

[11] S. J. Al-Homou d, Z. S . Habib, J. A. S. Abdul, et al., "Management of S acrococcygeal P ilonidal Disease," Saudi Medical Journal, Vol. 22, No. 9, Septemb er 2001, pp. 762-764.

[12] I. J. Mc Callum, P. M. King and J. Bruc e, "Healing by Primary Clos ure Vers us Open Heal ing aft er S urgery for Pilonidal Sinus: Systematic Review and Meta-Analysis," British Medical Journal, Vol. 3, No. 336, May 2008, pp. 975-976.

[13] I. McCallum, P. M. King and J. Bruce, "Healing by Primary Versus Secondar y Intention after Surgical Tr eatment for Pilonidal Sinus," Cochrane Database of Systematic Reviews, Vol. 17, No. 4, October 2007. 